\title{
CONSERVATION STATUS OF THREE RARE AND ENDEMIC SPECIES FROM TURKEY (Kalidium wagenitzii, Muscari adilii \& Verbascum gypsicola)
}

\author{
Ali Murat KESER*, Gül AYYILDIZ, Merve YILDIRIM, Ahmet Emre YAPRAK, Gül Nilhan TUĞ \\ Ankara University, Faculty of Science, Biology Department, 06100, Tandoğan, Ankara, TURKEY \\ Cite this article as: \\ Keser A.M., Ayyıldız G., Yıldırım M., Yaprak A.E. Tuğ G.N. 2020. Conservation Status of Three Rare and Endemic Species from Turkey (Kalidium \\ wagenitzii, Muscari adilii \& Verbascum gypsicola). Trakya Univ J Nat Sci, 21(2): 151-157, DOI: 10.23902/trkjnat.751851
}

Edited by:

Ioannis BAZOS

*Corresponding Author:

Ali Murat Keser

muratkeser05@hotmail.com

\section{ORCID ID:}

orcid.org/0000-0003-2245-3978

Key words:

Central Anatolia

Endemic

IUCN

Steppe

Threat factors

\begin{abstract}
In this study, we aimed to determine the population size and distribution areas and to reevaluate IUCN threat categories of Kalidium wagenitzii (Aellen) Freitag \& G. Kadereit, Muscari adilii M.B. Güner \& H. Duman and Verbascum gypsicola Vural \& Aydoğdu, which are endemics of the Central Anatolia region of Turkey. The three species have limited distribution areas and high risk of extinction as a result of human impact. The perennial halophytic species $K$. wagenitzii was found in 5 localities around Salt Lake (Tuz Gölü) and a total number of 6458 mature individuals were determined. The area of occupancy of the species is $36 \mathrm{~km}^{2}$ and the extent of occurrence is $213 \mathrm{~km}^{2}$. Uncontrolled use of water resources for agricultural purposes is a serious threat factor for the species. Kalidium wagenitzii is listed in EN category according to the IUCN Red List criteria. Muscari adilii prefers marly soils and its habitat type is formed by secondary succession after the destruction of Pinus nigra and oak forests. It is known from 3 localities around NallihanBeypazar1 with a population size of 6144 mature individuals. The area of occupancy and the extent of occurrence of the species is $12 \mathrm{~km}^{2}$ and $28 \mathrm{~km}^{2}$, respectively. The pressures on the species are road construction and increase of farmland, afforestation and factory establishment. According to the IUCN Red List criteria, the species is listed in CR category. Verbascum gypsicola is distributed on marly soils. It is known from 3 localities around Nallhan-Beypazar1 and one locality in Sivrihisar-Eskişehir with 2755 mature individuals in total. The area of occupancy of the species is $16 \mathrm{~km}^{2}$ and the extent of occurrence is $269 \mathrm{~km}^{2}$. Overgrazing and expansion of agricultural land, together with factory establishment are the major threats for this species, which is listed as EN in IUCN Red List.
\end{abstract}

Özet: Bu çalışma ile Türkiye'nin İç Anadolu bölgesi için endemik olan K. wagenitzii (Aellen) Freitag \& G. Kadereit, M. adilii M. B. Güner \& H. Duman ve V. gypsicola Vural \& Aydoğdu türlerinin popülasyon yapıları ve yayılış alanlarının belirlenmesi ve bunların sonucunda IUCN tehlike kategorilerinin tekrardan değerlendirilmesi amaçlanmıştır. Bu türlerin seçilmesinin nedeni sahip oldukları sınırlı yayılış alanları ile insan faktörü sonucu yüksek oranda yok olma riski taşımalarıdır. Çok yıllık halofitik $K$. wagenitzii türünün Tuz Gölü çevresinde 5 lokalitede yayılışı belirlenmiş ve toplam olgun birey sayıs 6458 olarak belirlenmiştir. Yaşam alanları toplamı $36 \mathrm{~km}^{2}$ olmasına karşın yayılıș alanı $213 \mathrm{~km}^{2}$ dir. Tarım amaçlı kontrolsüz su kaynaklarının kullanılması önemli bir tehdit faktörüdür. $K$. wagenitzii türünün tehdit kategorisi IUCN Kırmızı Liste kriterlerine göre EN olarak değerlendirilmiştir. $M$. adilii marnlı toprakları tercih etmekte ve habitat tipi $P$. nigra ve meşe ormanlarının yıkımı sonucu oluşan steplerdir. Nallıhan-Beypazarı çevresinde 3 lokaliteden bilinmekte ve olgun birey sayısı 6144 olarak belirlenmiştir. Yaşam alanları toplamı ve yayılış alanı sırasıyla 12 $\mathrm{km}^{2}$ ve $28 \mathrm{~km}^{2}$ dir. Tür üzerindeki baskılar yol inşası ve tarım alanlarının büyümesi, ağaçlandırma çalışmaları ve fabrika kurulumu olup CR kategorisinde değerlendirilmiştir. V. gypsicola marnlı topraklarda yayılmaktadır. Beypazarı-Nallıhan çevresinden 3 lokalite ve Sivirihisar-Eskişehir'de bir lokalite yayılışı bulunmaktadır. Olgun birey sayısı 2755 olarak belirlenmiştir. Yaşam alanları toplamı $16 \mathrm{~km}^{2}$ ve yayılış alanı $269 \mathrm{~km}^{2}$ dir. Aşırı otlatma ve tarım alanlarının büyümesi ile birlikte fabrika kurulumu tür üzerindeki baskılar olup EN olarak değerlendirilmiştir.

\section{Introduction}

All organisms from microorganisms to plants and even to humans are influenced by global changes. Species with restricted distribution areas or requiring specialized habitat needs are much more vulnerable to changes than the others (Iş1k 2011). The number of plant species in Turkey that have faced threats of any kind due to local or global changes are high in number. As in most parts of the world, according to historical and present records, there 
are many plant species in Turkey under the risk of extinction as a result of overgrazing, mining, erosion, expansion of agricultural areas and drought. According to the International Union for Conservation of Nature (IUCN), 2\% of all species on earth are extinct, $7 \%$ are critically endangered, $10 \%$ are endangered, and $19 \%$ are threatened (Global Biodiversity Outlook-3 2010). The number of species facing the risk of extinction is increasing and about 1500 plant species in Turkey were reported to be under the risk of extinction by the year 2009 (Vural 2009). To protect these species, it is important to make them well-known by the public, to know their population status, ecological preferences etc. (Vural 2009). For the conservation of biodiversity, there are two methods as in situ and ex situ conservations widely accepted in the world. In situ conservation protects the organism in its natural habitat, whereas in ex situ method conservation processes are conducted in elsewhere other than the natural habitat of the organism (Dokuzoğlu 1990).

IUCN provides some criteria for the determination of the status of rare, endemic and threatened species with an easily understandable and applicable system called the "IUCN Red List Categories and Criteria" (IUCN 2012). For the global extinction risks of species, IUCN provides accepted standards (Lamoreux et al. 2003, Rodrigues et al. 2006). The IUCN Red list provides valuable information not only for the list of species that are under the risk of extinction or some kind of threat but also for the habitats that are important for the conservation of these species (Collar 1993, 1996). According to these criteria, the threat category for each species can be determined.

Three of the rare and endemic species, Kalidium wagenitzii (Aellen) Freitag \& G. Kadereit, Muscari adilii M.B. Güner \& H. Duman and Verbascum gypsicola Vural \& Aydoğdu, of Central Anatolia (Turkey) were chosen for determination and re-evaluation of their IUCN threat categories. The most vulnerable taxa against habitat degradation and habitat fragmentation are the local endemics (Breggin et al. 2003) and are generally used for the determination of the presence of the protected areas of rare and endemic species (Bernardos et al. 2006). The criteria and categories provided by IUCN are important for the evaluation of the conservation status of threatened species and provide useful information for their conservation efforts (Vischi et al. 2004). Especially for rare and local endemics, it is important to have information about their life history, to predict their future trends and to plan conservation measures (García 2008).

The species provided below are mainly distributed around Ankara, except for $K$. wagenitzii which is distributed around Tuz Lake, within the borders of Konya and Aksaray provinces. All three species have special soil preferences, a factor that mainly restricts their distribution areas. Kalidium wagenitzii is perennial halophytic species distributed around Tuz Lake (Davis 1967, Sekmen et al. 2004). Tuz Lake and the surrounding areas were declared as an area of natural importance in 1992 and consequently as a Special Environmental Protection Area (SEPA) in
2000, the largest in Turkey with an area of $7.414 \mathrm{~km}^{2}$ (Mergen \& Karacaoğlu 2015).

Muscari adilii was found as three populations around Ankara where the soils are marly and the vegetation forms steps of secondary succession after the destruction of Pinus nigra J. F. Arnold and oak forests (Güner \& Duman 1999). The richest location of $M$. adilii in terms of the number of individuals is in Nallihan Bird Paradise wildlife protection and improvement area (Aslim et al. 2012).

Verbascum gypsicola is known from three localities in Ankara, where it grows on marly soils (Vural \& Aydoğdu 1993), and one locality in Eskişehir (Öztürk et al. 2018). The locality from Eskişehir province was unintentionally given wrong, and according to our data and herbarium records the correct locality of Eskişehir province was determined and studied (Öztürk et al. 2018 \& our data).

The aim of this study is to evaluate the present situation of population sizes, IUCN threat categories and distribution areas of $K$. wagenitzii, M. adilii and V. gypsicola.

\section{Materials and Methods}

Through the review of literature and visits to the main herbaria of Turkey (ANK, GAZI, OUFFE, ESSE) the distribution areas of each species were determined and based on the distributional data, the potential distribution areas were visited between 2016 and 2019 searching for new populations. To calculate the distribution areas, minimum convex polygons were drawn on Google Earth by using the GPS coordinates of the locatilities. Also, the distances between population were measured.

For each species, flower-bearing mature individuals in the populations were counted. The reason to count floral or fruity specimens is that they are capable of continuing their generation and often it is not possible to separate these species from other similar species without these characters. To determine the threat category, the area of occupancy (AOO) and the extent of occurrence (EOO) were drawn using Geospatial Conservation Assessment Tool program (GeoCAT- http://geocat.kew.org) according to Bachman et al. (2011) and were calculated according to IUCN recommended grid cell size $2 \times 2 \mathrm{~km}$. The threat category of each species was re-evaluated by using all these data considering the categories and criteria of the IUCN Red List (IUCN 2012, IUCN Standards and Petitions Committe 2019).

\section{Results}

The results about each taxon are given in an alphabetical order and each of the three species is evaluated according to IUCN Red List Categories and Criteria (IUCN 2012, IUCN Standards and Petitions Committee 2019).

\section{Kalidium wagenitzii}

Kalidium wagenitzii has five subpopulations in salt marshes around Tuz Lake with 6458 mature individuals (see Table 1 for detailed information about each subpopulation). The AOO and EOO are $36 \mathrm{~km}^{2}$ and 213 $\mathrm{km}^{2}$, respectively (Fig. 1). 


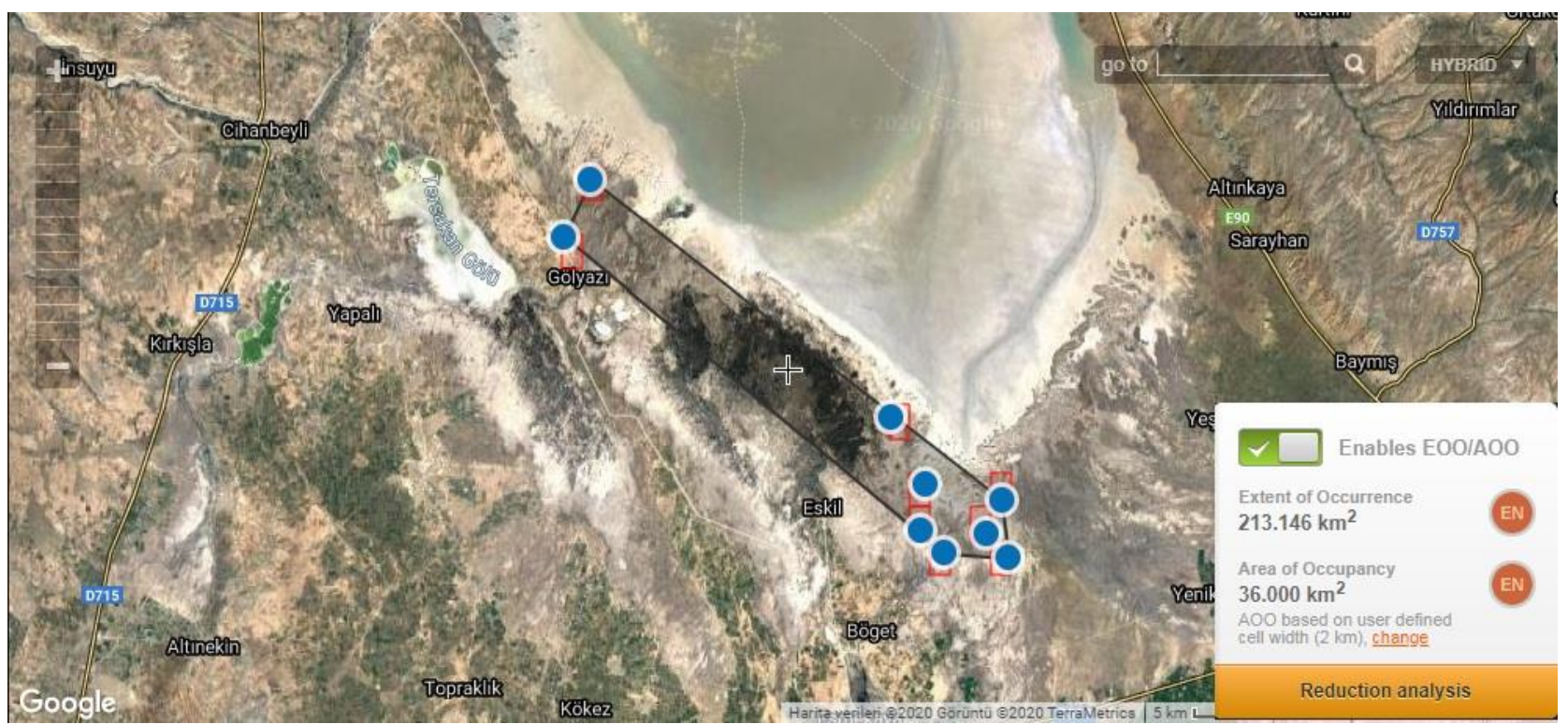

Fig. 1. The extent of occurrence of K. wagenitzii.

Table 1. Number of mature individuals, distribution area, and threat factors of $K$. wagenitzii.

\begin{tabular}{|c|c|c|c|c|}
\hline Locality & $\begin{array}{l}\text { Number of } \\
\text { mature } \\
\text { individuals }\end{array}$ & GPS data & $\begin{array}{l}\text { The surface } \\
\text { area occupied } \\
\text { by each } \\
\text { subpopulation }\end{array}$ & Threat factors \\
\hline $\begin{array}{l}\text { B4, Konya: Cihanbeyli, } 4 \mathrm{~km} \text { east of } \\
\text { Gölyazı, } 918 \mathrm{~m}\end{array}$ & 1371 & $\begin{array}{l}\text { N } 38^{\circ} 36^{\prime} 46^{\prime \prime} \\
\text { E } 33^{\circ} 11^{\prime} 34^{\prime \prime}\end{array}$ & $7.3 \mathrm{~km}^{2}$ & $\begin{array}{l}\text { Illegal housing and legal wells, un- } \\
\text { controlled and illegal wells. }\end{array}$ \\
\hline $\begin{array}{l}\text { A- B4, Aksaray: Eskil, between Eskil } \\
\text { and Yenikent, } 910 \mathrm{~m}\end{array}$ & 150 & $\begin{array}{l}\text { N } 38^{\circ} 27^{\prime} 10^{\prime \prime} \\
\text { E } 33^{\circ} 29^{\prime} 60^{\prime \prime}\end{array}$ & $0.036 \mathrm{~km}^{2}$ & $\begin{array}{l}\text { Legal wells and uncontrolled and } \\
\text { illegal wells. }\end{array}$ \\
\hline $\begin{array}{l}\text { B- B4, Aksaray: Eskil, between Eskil } \\
\text { and Yenikent, } 910 \mathrm{~m}\end{array}$ & 40 & $\begin{array}{l}\text { N } 38^{\circ} 25^{\prime} 05^{\prime \prime} \\
\text { E } 33^{\circ} 30^{\prime} 13^{\prime \prime}\end{array}$ & $0.001 \mathrm{~km}^{2}$ & $\begin{array}{l}\text { Legal wells and uncontrolled and } \\
\text { illegal wells. }\end{array}$ \\
\hline $\begin{array}{l}\text { C- B4, Aksaray: Eskil, between Eskil } \\
\text { and Yenikent, } 910 \mathrm{~m}\end{array}$ & 40 & $\begin{array}{l}\text { N } 38^{\circ} 24^{\prime} 29^{\prime \prime} \\
\text { E } 33^{\circ} 34^{\prime} 14^{\prime \prime}\end{array}$ & $0.001 \mathrm{~km}^{2}$ & $\begin{array}{l}\text { Legal wells and uncontrolled and } \\
\text { illegal wells. }\end{array}$ \\
\hline $\begin{array}{l}\text { D- B4, Aksaray: Eskil, between Eskil } \\
\text { and Yenikent, } 910 \mathrm{~m}\end{array}$ & 4857 & $\begin{array}{l}\text { N } 38^{\circ} 22^{\prime} 50^{\prime \prime} \\
\text { E } 33^{\circ} 32^{\prime} 44^{\prime \prime}\end{array}$ & $7.64 \mathrm{~km}^{2}$ & $\begin{array}{l}\text { Legal wells and uncontrolled and } \\
\text { illegal wells. }\end{array}$ \\
\hline Total Number of Individuals & 6458 & & & \\
\hline
\end{tabular}

The subpopulations between Eskil and Yenikent were given by adding letters $A$ to $D$ because of the lack of discriminative definition of the area. GPS coordinates of each subpopulation were also given (Table 1). The distance between the two main subpopulations from Gölyazı and Eskil is about $35 \mathrm{~km}$. The subpopulations at Eskil are close to each other and the distance between them are as follows; The distance between A and B is 3.93 $\mathrm{km}, \mathrm{A}$ and $\mathrm{C}$ is $7.83 \mathrm{~km}$. The distance between $\mathrm{B}$ and $\mathrm{C}$ subpopulations is 5.91 , and that of B to D is $4.70 \mathrm{~km}$ and the distance between $\mathrm{C}$ and $\mathrm{D}$ subpopulations is $4.35 \mathrm{~km}$.

\section{Muscari adilii}

Muscari adilii is known from three localities (Güner \& Duman 1999) with a total population size of 6114 mature individuals. The detailed information about each subpopulation is given in Table 2. The AOO and the EOO are $12 \mathrm{~km}^{2}$ and $28 \mathrm{~km}^{2}$, respectively (Fig. 2).

The distance between the subpopulations of Nallihan Bird Sanctuary locality and Hirkatepe locality is $16.55 \mathrm{~km}$ and between Nallihan Bird Sanctuary locality and Çoban Ahmet Fountain locality is $22.25 \mathrm{~km}$. The distance between the localities from Beypazar1, Hirkatepe and Çoban Ahmet Fountain is $5.78 \mathrm{~km}$.

\section{Verbascum gypsicola}

There are four known localities of $V$. gypsicola (Vural \& Aydoğdu 1993, Öztürk et al. 2018) with 2755 mature individuals in total. Detailed information about each subpopulation is given in Table 3 . The AOO and the EOO are $16 \mathrm{~km}^{2}$ and $269 \mathrm{~km}^{2}$, respectively (Fig. 3). 


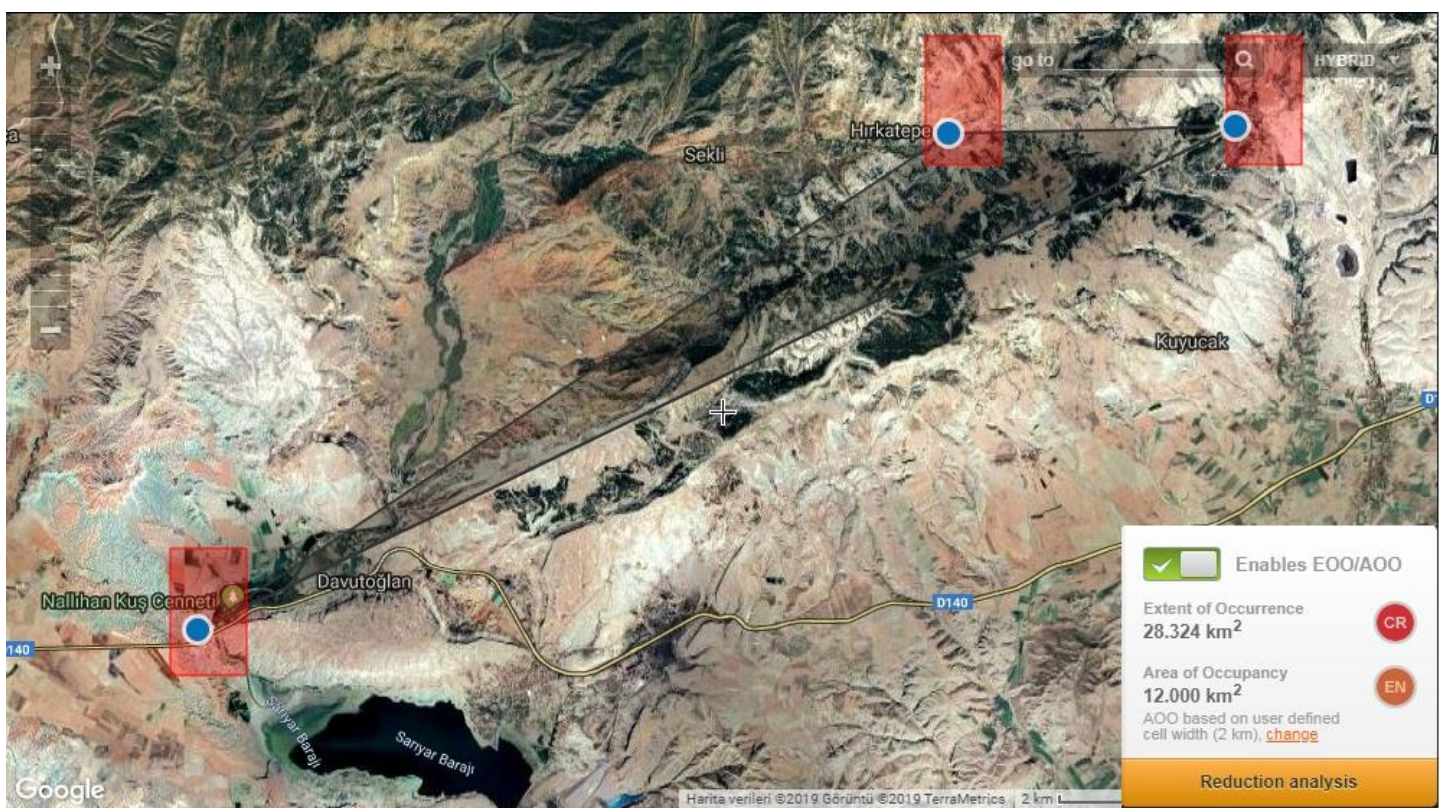

Fig. 2. The extent of occurrence of $M$. adilii.

Table 2. Number of mature individuals, distribution area and threat factors of $M$. adilii.

\begin{tabular}{|c|c|c|c|c|}
\hline Location & $\begin{array}{l}\text { Number of } \\
\text { mature } \\
\text { individuals }\end{array}$ & GPS data & $\begin{array}{c}\text { The surface } \\
\text { area occupied } \\
\text { by each } \\
\text { subpopulation }\end{array}$ & Threat factors \\
\hline $\begin{array}{l}\text { Ankara: Nallıhan, Nallıhan. SW of Nallıhan } \\
\text { Bird Sanctuary, } 500 \mathrm{~m} \text {. }\end{array}$ & 5795 & $\begin{array}{l}\text { N } 40^{\circ} 06^{\prime} 17^{\prime \prime} \\
\text { E 031 } 355^{\prime} 29^{\prime \prime}\end{array}$ & $0.0734 \mathrm{~km}^{2}$ & Close to road construction \\
\hline $\begin{array}{l}\text { Ankara: Beypazarı, Hırkatepe. Uyku De. } 900- \\
950 \mathrm{~m} .\end{array}$ & 119 & $\begin{array}{l}\text { N } 40^{\circ} 11^{\prime} 53^{\prime \prime} \\
\text { E } 031^{\circ} 50^{\prime} 20^{\prime \prime}\end{array}$ & $0.001 \mathrm{~km}^{2}$ & $\begin{array}{l}\text { Erosion owing to road } \\
\text { construction }\end{array}$ \\
\hline $\begin{array}{l}\text { Ankara: Beypazarı, Beypazar1-Sekli village. } \\
\text { Doğandede Hill, above Çoban Ahmet } \\
\text { Fountain, } 990 \mathrm{~m} \text {. }\end{array}$ & 200 & $\begin{array}{l}\text { N } 40^{\circ} 11^{\prime} 26^{\prime \prime} \\
\text { E } 031^{\circ} 46 ' 17^{\prime \prime}\end{array}$ & $0.001 \mathrm{~km}^{2}$ & $\begin{array}{l}\text { Expansion of agricultural } \\
\text { areas, afforestation, factory } \\
\text { construction }\end{array}$ \\
\hline Total Number of Individuals & 6114 & & & \\
\hline
\end{tabular}

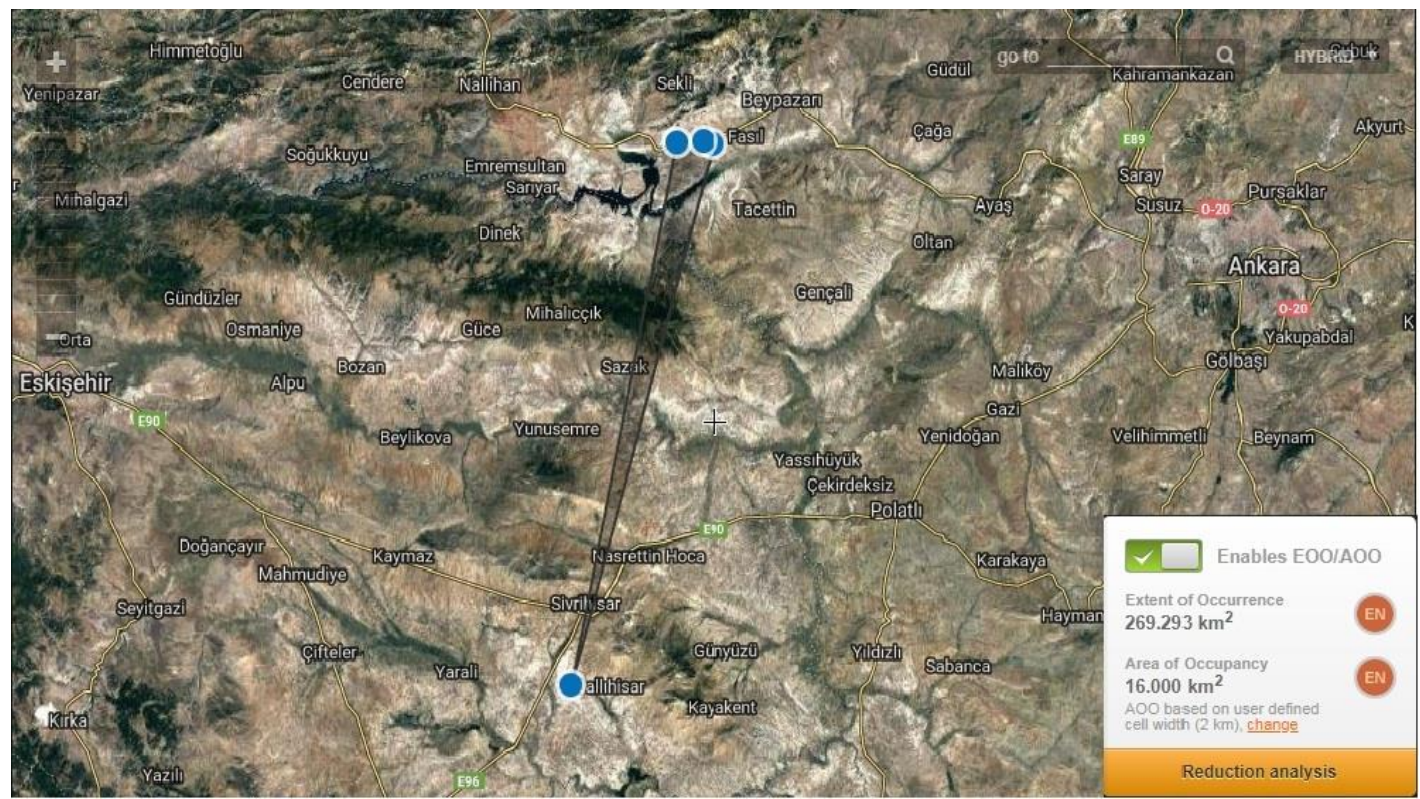

Fig. 3. The extent of occurrence of Verbascum gypsicola. 
Table 3. Number of mature individuals, distribution area and threat factors of Verbascum gypsicola.

\begin{tabular}{|c|c|c|c|c|}
\hline Location & $\begin{array}{c}\text { Number of } \\
\text { mature } \\
\text { individuals }\end{array}$ & GPS data & $\begin{array}{c}\text { The surface } \\
\text { area occupied } \\
\text { by each } \\
\text { subpopulation }\end{array}$ & Threat factors \\
\hline $\begin{array}{l}\text { Ankara: Beypazarı-Çayırhan, } 2 \mathrm{~km} \text { to Çayırhan, } \\
\text { Solta Pass, } 580 \mathrm{~m} \text {. }\end{array}$ & 1535 & $\begin{array}{l}\text { N } 40^{\circ} 06^{\prime} 28^{\prime \prime} \\
\text { E } 031^{\circ} 42^{\prime} 54^{\prime \prime}\end{array}$ & $0.0088 \mathrm{~km}^{2}$ & Gypsum quarry \\
\hline Ankara: Beypazarı, Kösebükü village, 600 m & 700 & $\begin{array}{l}\text { N } 40^{\circ} 06 ' 20^{\prime \prime} \\
\text { E } 031^{\circ} 47^{\prime} 17^{\prime \prime}\end{array}$ & $0.0285 \mathrm{~km}^{2}$ & $\begin{array}{l}\text { Expansion of agricultural } \\
\text { areas and overgrazing }\end{array}$ \\
\hline $\begin{array}{l}\text { Ankara: Beypazarı, } 15 \mathrm{~km} \text { from Beypazarı to } \\
\text { Çayırhan, } 625 \mathrm{~m} \text {. }\end{array}$ & 335 & $\begin{array}{l}\text { N } 40^{\circ} 06^{\prime} 20^{\prime \prime} \\
\text { E } 31^{\circ} 46 ' 30^{\prime \prime}\end{array}$ & $0.0734 \mathrm{~km}^{2}$ & $\begin{array}{l}\text { Expansion of agricultural } \\
\text { areas and overgrazing }\end{array}$ \\
\hline $\begin{array}{l}\text { Eskişehir: Sivrihisar, between Yeşilköy village- } \\
\text { and Aşağıkepen, } 947 \mathrm{~m} .\end{array}$ & 185 & $\begin{array}{l}\text { N } 39^{\circ} 20^{\prime} 04^{\prime \prime} \\
\text { E } 31^{\circ} 31^{\prime} 11^{\prime \prime}\end{array}$ & $0.0011 \mathrm{~km}^{2}$ & $\begin{array}{l}\text { Expansion of agricultural } \\
\text { areas and overgrazing }\end{array}$ \\
\hline Total Number of Individuals & 2755 & & & \\
\hline
\end{tabular}

Table 4. New populations/subpopulations found during the study.

\begin{tabular}{|c|c|c|}
\hline Species & Locality & Gps \\
\hline \multirow{4}{*}{ Kalidium wagenitzii } & A-B4, Aksaray: Eskil, between Eskil-Yenikent, 910 m. & $\begin{array}{l}\text { N } 38^{\circ} 27^{\prime} 10^{\prime \prime} \\
\text { E } 33^{\circ} 29^{\prime} 60^{\prime \prime}\end{array}$ \\
\hline & B- B4, Aksaray: Eskil, between Eskil-Yenikent, 910 m. & $\begin{array}{l}\text { N } 38^{\circ} 25^{\prime} 05^{\prime \prime} \\
\text { E } 33^{\circ} 30^{\prime} 13^{\prime \prime}\end{array}$ \\
\hline & C- B4, Aksaray: Eskil, between Eskil-Yenikent, 910 m. & $\begin{array}{l}\text { N } 38^{\circ} 24^{\prime} 29^{\prime \prime} \\
\text { E } 33^{\circ} 34^{\prime} 14^{\prime \prime}\end{array}$ \\
\hline & D- B4, Aksaray: Eskil, between Eskil-Yenikent, 910 m. & $\begin{array}{l}\text { N } 38^{\circ} 22^{\prime} 50^{\prime \prime}, \\
\text { E } 33^{\circ} 32^{\prime} 44^{\prime \prime}\end{array}$ \\
\hline Verbascum gypsicola & Ankara: Beypazarı, $15 \mathrm{~km}$ from Beypazarı to Çayırhan, $625 \mathrm{~m}$. & $\begin{array}{l}\text { N } 40^{\circ} 06 ' 20^{\prime \prime} \\
\text { E } 31^{\circ} 46^{\prime} 30^{\prime \prime}\end{array}$ \\
\hline
\end{tabular}

The mean distance between the locality at Sivrihisar and the 3 localities at Beypazar1-Nallihan is $89 \mathrm{~km}$. The distance between the localities at Beypazarı and Nallıhan is $5.10 \mathrm{~km}$ between Solta Pass and " $15 \mathrm{~km}$ from Beypazar1 to Çayırhan" 6.37 between Solta Pass and Kösebükü and is $1.48 \mathrm{~km}$ between " $15 \mathrm{~km}$ from Beypazarı to Çayırhan" and Kösebükü.

According to the literature search, the distribution area for $K$. wagenitzii is the area between Eskil district and its dump area. After the field studies conducted within this study, new populations close to the known distribution area were found and the exact locations and areas of each subpopulation were defined. Also, one new locality for $V$. gypsicola is found.

\section{Discussion}

\section{IUCN status of Kalidium wagenitzii}

Kalidium wagenitzii fulfils the below criteria:

Criterion B, Geographic range in the form of either B1 (EOO) or B2 (AOO) or both: Under this criterion, the species fulfils both $1 \mathrm{a}$ and $1 \mathrm{~b}$ i, ii and iii. Even though there are 5 localities mentioned for $K$. wagenitzii for the determination of threat category in Fig. 1 and Table 1, these subpopulations are under the influence of the same risk factors so they were accepted as one locality according to IUCN (2012, Standards and Petitions Committee 2019).

The main difficulty for all the plant species around Tuz Lake is the water loss because of global climate change, wrong irrigation practices, and un-controlled and/or illegal wells. The groundwater level at AksarayEskil, close to the distribution area of $K$. wagenitzii, has dropped about 4 meters between 2000 and 2004 and this dropping of water level is almost equal to the water level dropping in 25 years between 1975 and 2000 (Arslan \& Göçmez 2007). The main threat for $K$. wagenitzii populations is the habitat loss, habitat fragmentation and lack of water. Tuz Lake water surface area decreased about $400 \mathrm{~km}^{2}$ between the years of 2000-2015 (Orhan et al. 2017).

These water surface changes influence both terrestrial and marsh plants that need different levels of water alike, and the change in habitat structure causes shrinking of populations.

According to EOO and AOO values, the threat category should be EN [B1 ab (i,ii,iii) + B2 ab (i,ii,iii)]. However, the quantitative data from our field studies and the available literature data show that the species is under severe pressure. 


\section{IUCN status of Muscari adili}

Muscari adilii fulfils the below criteria:

Criterion $\mathrm{B}$, which is the geographic range in the form of either B1 (EOO) or B2 (AOO) or both. The species is known from only three localities with $28 \mathrm{~km}^{2}$ of EOO and $12 \mathrm{~km}^{2}$ of AOO. These subpopulations are declining and it is estimated that they will continue to decline in the future. (i) extent of occurrence, (ii) area of occupancy and (iii) area, extent and quality of habitat are affected. So the IUCN status is CR [B1 ab (i,ii,iii)].

Muscari adilii is found in localities close to road construction areas and agricultural areas. Road construction cause habitat fragmentation, afforestation and the expansion of agricultural areas increase the habitat loss. The establishment of a factory close to Çoban Ahmet Fountain has put the relevant subpopulation at risk of extinction.

Muscari adilii is included in CR [B1 ab (i,ii,iii)] according to EOO values in IUCN Red List criteria and categories.

However, the number of mature individuals is high and the threats for this species are given in Table 2. The threats that affect and place this species at risk will continue to act in the future, and therefore, M. adilii is placed in the CR category.

\section{IUCN status of Verbascum gypsicola}

Verbascum gypsicola fulfils the following criteria:

Criterion B, which is the geographic range in the form of either B1 (EOO) or B2 (AOO) or both. The species is known from only 4 locations which are under severe pressure (Table 3), and the EOO is $269 \mathrm{~km}^{2}$ and the AOO is $16 \mathrm{~km}^{2}$. The decline of the subpopulations is estimated to continue in the future; (i) extent of occurrence (ii) area of occupancy (iii) area, extent and quality of habitat are affected. Therefore, the IUCN status is EN [B1 ab (i,ii,iii)+ B2 ab (i,ii,iii)].

The largest subpopulation of $V$. gypsicola is surrounded by fences, which protect the population against threats related to overgrazing and expansion of agricultural areas. However, the establishment of a new

\section{References}

1. Arslan, V. \& Göçmez, G. 2007._Tuzgölü havzasında yeraltı suyunun yok oluşu (Eşmekaya-Sultan Hanı örneği), Selçuk Üniversitesi Mühendislik-Mimmarlı Fakültesi Dergisi, 23(1-2), 15-164.

2. Aslım, G., Yiğit, A., İzmirli, S. \& Yaşar, A. 2012. Hayvan koruma kavramı ve biyoetik çerçevesinde yaban hayatı koruma ve yaban hayatı geliştirme sahaları, Kafkas Üniversitesi Veterinerlik Fakültesi Dergisi, 18 (4): 657662. DOI:10.9775/kvfd.2012.6217

3. Bachman, S., Moat, J., Hill, A.W., De la Torre, J. \& Scott, B. 2011. Supporting Red List threat assessments with GeoCAT: Geospatial conservation assessment tool. ZooKeys, 150: 117-126. DOI: 10.3897/zookeys.150.2109 gypsum factory within $500 \mathrm{~m}$ of the population poses a serious danger to the population.

The threat category of $V$. gypsicola was initially determined as EN in the Red Data Book of Turkish Plants (Ekim et al. 2000) but afterwards re-evaluated as CR by Eker et al. (2015).

EOO and AOO values, the distribution area of each subpopulation, the total number of mature individuals and the number of mature individuals in each subpopulation, and the threat factors over this species are provided in Table 3. In the view of our findings and estimations, the species is here evaluated in the EN category, being in accordance with the first evaluation by Ekim et al. (2000).

The number of mature individuals of $\mathrm{B}$ and $\mathrm{C}$ subpopulations of $K$. wagenitzii at Eskil is 40 for both subpopulation. As a precaution against the extinction of these subpopulations, individuals from D subpopulation with a high number of individuals should be transferred.

Çoban Ahmet Fountain subpopulation of M. adilii is under the threat of factory construction, for the protection of the genetic diversity of this subpopulation, new potential habitats should be determined in areas very close to this subpopulation and in these potential habitats new populations should be grown from the seeds of Çoban Ahmet Fountain subpopulation. The number of mature individuals of all subpopulations of $V$. gypsicola is low and should be increased. The Yeşilköy subpopulation is relatively isolated from all other subpopulations and is under the threat of agricultural area expansions and overgrazing, so it is suggested to fence the area where the individuals occupy and use informative signs.

Certain education programs intended for local people may provide protection for these species. We also recommend that in-situ and ex-situ conservation actions should be started for the conservation of each species.

\section{Acknowledgement}

Ankara University Research Fund (Project no: 18L0430016), Republic of Turkey Ministry of Agriculture and Forestry, General Directorate of Nature Conservation and National Parks and Prof. Dr. Mecit VURAL are kindly acknowledged.

4. Bernardos, S., Amado, A. \& Amich, F. 2006. The narrow endemic Scrophularia valdesii Ortega-Olivencia and Devesa (Scrophulariaceae) in the Iberian Peninsula: an evaluation of its conservation status. Biodiversity and Conservation 15: 4027-4043.

5. Breggin, L.K., George, S.M. \& Pencak, E.H. 2003. Planning for Biodiversity: Authorities in State Land Use Laws. Environmental Law Institute \& Defenders of Wildlife. Washington D.C. 113 pp.

6. Collar, N.J. 1993. Red data books, action plans, and the need for site-specific synthesis. Species 21 and 22: 132133. 
7. Collar, N.J. 1996. The reasons for red data books. Oryx, 30:121-130.

8. Davis, P.H., 1967. Flora of Turkey and the East Aegean Islands, vol. 2. Edinburgh University Press, Edinburgh.

9. Dokuzoğlu, M. 1990. Plant Genetic Resource. Biological Existences of Turkey. Foundation of Turkey Environmental Problems, Ankara, 235 pp.

10. Eker, İ., Vural, M. \& Arslan, S. 2015. Ankara ili'nin damarlı bitki çeşitliliği ve korumada öncelikli taksonları. Bă̆ Bahçe Bilim Dergisi. 2(3): 57-114.

11. Ekim T., Koyuncu M., Vural M., Duman H., Aytaç Z. \& Adıgüzel N. 2000. Türkiye Bitkileri Kırmızı Kitabı. 100. Y11 Üniversitesi ve Türkiye Tabiatını Koruma Derneği, Ankara.

12. García, M.B. 2008. Life history and population size variability in a relict plant: Different routes towards longterm persistence. Diversity and Distributions, 14: 106-113.

13. GeoCAT, Geospatial Conservation Assessment Tool. 2019. http://geocat.kew.org/editor (Data accessed: 20.06.2020)

14. Global Biodiversity Outlook-3. 2010. Secretariat of the convention on biological diversity. http://www.cbd.int/doc/publications/gbo/gbo3-final-en.pdf (Data accessed: 20.06.2020)

15. Güner, B. \& Duman, H. 1999. A new species of Muscari Mill. (Liliaceae) from Central Anotolia. Karaca Arboretum Magazine, 5: 59-66.

16. Iş1k, K. 2011. Rare and endemic species: why are they prone to extinction? Turkish Journal of Botany, 35: 411417.

17. IUCN. 2012. "IUCN Red List Categories and Criteria: Version 3.1. Second edition", Gland, Switzerland and Cambridge, UK: IUCN, http://s3.amazonaws.com/iucnredlistnewcms/staging/public/attachments/3097/redlist_cats_crit _en.pdf_(Date accessed: 15.06.2020).

18. IUCN Standards and Petitions Committee. 2019. Guidelines for using the IUCN Red List categories and criteria. Version $14 . \quad$ Available from: http://www.iucnredlist.org/ documents/RedListGuidelines.pdf

19. Lamoreux, J., Akçakaya, R., Bennun, L., Collar, N.J., Boitani, L., Brackett, D., Brautigam, A., Brooks, T.M, da Fonseca, G.A.B., Russell, A., Mittermeier, R.A., Rylands, A.B., Gardenfors, U., Hilton-Taylor, C., Mace, G., Stein, B.A. \& Stuart S. 2003. Value of the IUCN Red List. Trends in Ecology \& Evolution, 18: 214-215.

20. Mergen, O. \& Karacaoglu, C. 2015. Tuz Lake special environment protection area, Central Anatolia, Turkey: The EUNIS habitat classification and habitat change detection between 1987 and 2007, Ekoloji 24, 95: 1-9.

21. Orhan, O., Yalvaç, S. \& Ekercin, S. 2017. Investigation of climate change impact on Salt Lake by statistical methods, International Journal of Environment and Geoinformatics, 4(1) 54-62.

22. Öztürk, D., Sezer, O., Koyuncu, O. \& Ocak, A. 2018. Flora of gypsiferous and marl soils in Eskisehir (Turkey), Biological Diversity and Conservation, 11/2: 137-15.

23. Rodrigues, A.S.L., Pilgrim, J.D., Lamoreux, J.L., Hoffmann, M. \& Brooks T.M. 2006. The value of the Red List for conservation. Trends in Ecology \& Evolution, 21:71-76

24. Sekmen, A.H., Özdemir, F. \& Türkan, İ. 2004. Effects of salinity, light, and temperature on seed germination in Turkish endangered halophyte, Kalidiopsis wagenitzii (Chenopodiaceae), Israel Journal of Plant Scienses, 52, 2130 .

25. Vischi, N., Natale, E. \& Villamil, C. 2004. Six endemic plant species from central Argentina: An evaluation of their conservation status. Biodiversity and Conservation, 13: 997-1008.

26. Vural, M. \& Aydoğdu, M. 1993. A new species from central Anatolia Verbascum gypsicola (Scrophulariaceae). Karaca Arboretum Magazine, 2(2): 75-78.

27. Vural, M. 2009. Türkiye'nin tehdit altındaki bitkileri, Bağbahçe, Çevre Bahçe Çiçek Dergisi, 23: 12-14. 